\title{
KINETIKA TRANSPOR Cu(II) OLEH ZAT PEMBAWA OKSIN DENGAN DAN TANPA ASAM OLEAT MELALUI MEMBRAN CAIR FASA RUAH
}

\author{
Refinel dan Emdeniz \\ Laboratorium Kimia Fisika, Jurusan Kimia, FMIPA, Universitas Andalas, Padang
}

\begin{abstract}
Transport of $\mathrm{Cu}$ (II) ions with and without oleat acid additive through bulk liquid membrane has been fullfill the kinetic lows of consecutive irreversible first reaction by oxine as carrier in chloroform membrane. Additions of oleat acid $1.575 \times 10^{-3} \mathrm{M}$ could increase $\mathrm{Cu}(\mathrm{II})$ transport affectivity on interface of membrane-source phase and receiving-membrane phase. Transport rate constanta value of $\mathrm{Cu}(\mathrm{II})$ ions entrance $\left(\mathrm{k}_{1}\right) \quad 0.0454 /$ minute and the membrane exit rate $\left(\mathrm{k}_{2}\right)$ $0.0364 /$ minute at $301 \mathrm{~K}$ with activation energy $51.471 \mathrm{~kJ} / \mathrm{mol}$ and without oleat acid rate constanta $\left(\mathrm{k}_{1}\right) \quad 0.0236 /$ minute, $\left(\mathrm{k}_{2}\right) \quad 0.0193 /$ minute with activation energy $55.2499 \mathrm{~kJ} / \mathrm{mol}$ at the same condition.
\end{abstract}

Keywords : bulk liquid membrane, oxine, oleat acid, copper ions

\section{DAFTAR PUSTAKA}

1. M. Mulder, Basic Principle of Membran Tecnology, Kluwer Acedemic Publibsher, Dordrencht, 1991, 244-259.

2. D. Maria, et. al., Model Experiment to Test the Use of a Liquid Membrane for Saparation and Preconcentrat of Copper from Natural Water, J. Anal. Chem. Acta., 506: 81-86, (2004).

3. Ismono, Ekstraksi Pelarut, Diktat Kuliah S-2 Kimia ITB, Bandung, 1984, 451-455.

4. H. Korkmaz Alpogus, S. Memon, M. Ersoz and M. Yilmaz, Transport of $\mathrm{Hg}^{2+}$ Through Bulk Liquid Membrane Using a Bis-calix(4)arene Nitrile Derivative as a
Carrier: Kinetic Analysis, J. Chem., 26: 477-480, (2002).

5. O. N. Tetra. Transpor antar Fasa dari Ion Tembaga (II) Melalui Membran Cair Fasa Ruah. Skripsi Sarjana Kimia, Universitas Andalas, 2000.

6. R. J. Milton, Surfactans and Interfacial Phenomena, A. Wiley Interscince Publication, John Willey and Sons, New York, 1978, 55-58.

7. Valenzuela et,al., Influence of Nonionic Surfactant Compound on Coupled Transport of Copper (II) Through a Liquid Membrane, J. Chil.Chem., 48, (2003).

8. T. S. Kusuma, Kinetika Kimia, Jurusan Kimia Fakultas MIPA Universitas Andalas, 1981. 